\title{
Cladocera (Crustacea: Branchiopoda) in Indian hot water springs
}

\author{
S. Padhye', A.A. Kotov ${ }^{2}$ \\ ${ }^{1}$ Laboratory for Zooplankton Studies, Dept. of Zoology, University of Pune, Pune-411007, India. \\ e-mail: sameer.m.padhye@gmail.com \\ ${ }^{2}$ A.N. Severtsov Institute of Ecology and Evolution, Leninsky Prospect 33, Moscow 119071, Russia. \\ e-mail: alexey-a-kotov@yandex.ru
}

\begin{abstract}
We found two species of Cladocera (Crustacea: Branchiopoda), namely Latonopsis cf. australis Sars, 1888 (family Sididae) and Alona cambouei Guerne et Richard, 1893 (family Chydoridae), in the Unhere hot water springs near Pali, State of Maharashtra, India at temperatures of $34.5-36.7^{\circ} \mathrm{C}$. Our finding is the first record of cladocerans with exact species determination in hotsprings of the Oriental zone.
\end{abstract}

KEY WORDS: Anomopoda, fauna, India, abiotic factors, temperature.

\section{Cladocera (Crustacea: Branchiopoda) в индийских горячих источниках}

\author{
С. Падхиㄹ, А.А. Котов ${ }^{2}$ \\ ${ }^{1}$ Лаборатория исследований зоопланктона, Кафедра зоологии, Университет Пуне, Пуне- \\ 411007, Индия. \\ e-mail: sameer.m.padhye@gmail.com \\ ${ }^{2}$ Институт проблем экологии и эволюции им. А. Н. Северцова РАН, Ленинский проспект, 33 , \\ Москва 119071, Россия. \\ e-mail: alexey-a-kotov@yandex.ru \\ РЕЗЮМЕ: Мы нашли, что два вида Cladocera (Crustacea: Branchiopoda), а именно, \\ Latonopsis cf. australis Sars, 1888 (семейство Sididae) и Alona cambouei Guerne et \\ Richard, 1893 (семейство Chydoridae), весьма обычны в горячих источниках Унхере \\ около города Пали, Штат Махараштра, Индия при температурах $34,5-36,7$ ㄷ․ Это \\ первое сообщение о находке кладоцер, определенных до вида, в горячих источниках \\ Ориентальной биогеографической зоны.
}

КЛЮЧЕВЫЕ СЛОВА: Anomopoda, фауна, Индия, абиотические факторы, температура. 
Table 1. Physico-chemical properties of Pali hot springs. Таблица 1. Физико-химические характеристики горячих источников Пали.

\begin{tabular}{|l|c|c|c|c|}
\hline Physico-chemical properties & April 2009 & June 2009 & February 2010 & May 2010 \\
\hline Temperature, ${ }^{\circ} \mathrm{C}$ & 35.7 & 36.7 & 34.5 & 35.0 \\
\hline $\mathrm{pH}$ & 7.38 & 7.5 & 7.0 & 7.15 \\
\hline${\text { Conductivity, } \mu \mathrm{S} \mathrm{cm}^{-1}}^{-1}$ & 4.2 & 4.5 & 4.86 & 4.85 \\
\hline T.D.S., $\mathrm{mg}^{-1}$ & 3.1 & 3.18 & 3.3 & 3.43 \\
\hline Salinity, \%o & 2.4 & 2.52 & 2.6 & 2.61 \\
\hline
\end{tabular}

\section{Introduction}

The literature about flora and fauna of hot springs in the Oriental zone is fragmentary (Kirtikar, 1968; Thomas, Gonzalves, 1968; Jana, 1971). There is only a single previous record of Cladocera in hot springs (Jana, 1971) without illustrations and with generic determinations only, viz. Daphnia and Diaphanosoma in a hot spring in West Bengal at $37-51{ }^{\circ} \mathrm{C}$, together with the rotifer genera Lecane, Monostyla, and Euchlanis, and some ostracods. But any findings of the cladocerans in such extreme conditions are important, because they improve our knowledge on cladoceran diversity (Forró et al., 2008). This short communication is aimed to describe our finding of cladocerans in hot springs at Pali, India.

\section{Material and methods}

The hot springs of Pali are located in the village of Unhere Budruk near the town of Pali, Kolaba District, State of Maharashtra, India $\left(18^{\circ} 33^{\prime} 25.20^{\prime \prime} \mathrm{N}, 73^{\circ} 13^{\prime} 05.34^{\prime \prime} \mathrm{E}\right)$. They erupt into three tanks of about $2 \times 2 \times 2 \mathrm{~m}$, from where the water overflows to form neighboring puddles of tepid water (Kirtikar, 1968).

The qualitative samples were collected in February, April, and June of 2009, February and May of 2010 from one of the tanks by plankton net. The temperature, $\mathrm{pH}$, conductivity, total dissolved solids and salinity were recorded using a Multi-Parameter Probe (Eutech Instru- ments) during each sampling (Table 1). The samples were preserved in formalin, sorted under an Olympus Magnus (MS-24) dissecting binocular microscope, and finally studied under an Olympus binocular microscope (CH 20i). Photos were made using a digital camera Sony DSC-W35 attached to the latter. For identification of the species 10 parthenogenetic females of each species were used. The samples are saved in the personal collections of the authors.

\section{Results and discussion}

Two species of cladocerans were found: Latonopsis cf. australis Sars, 1888 (family Sididae) and Alona cambouei Guerne et Richard, 1893 (family Chydoridae) (Figs 1-4). Our samples were not quantitative, but total number of both species in all series of 2009 was quite high, and each time Latonopsis was more abundant. Both species were absent in two 2010 collections.

Among the species of Latonopsis Sars, 1888, the L. australis group is diagnosed by: (1) three long naked setae on the postero ventral corner of valve with length of about $70 \%$ of body length, (2) postabdomen relatively small, with 7-9 small teeth closer to distal end, (3) postabdominal claws with two basal spines; (4) not more than 12 setae on two-segmented antennal exopod; (5) length of female not more than $1.8 \mathrm{~mm}$ (Korovchinsky, 2004). Latonopsis cf. australis was never recorded before from hot springs, although it was found in various freshwater habitats in India (Korovchinsky, 2004). 

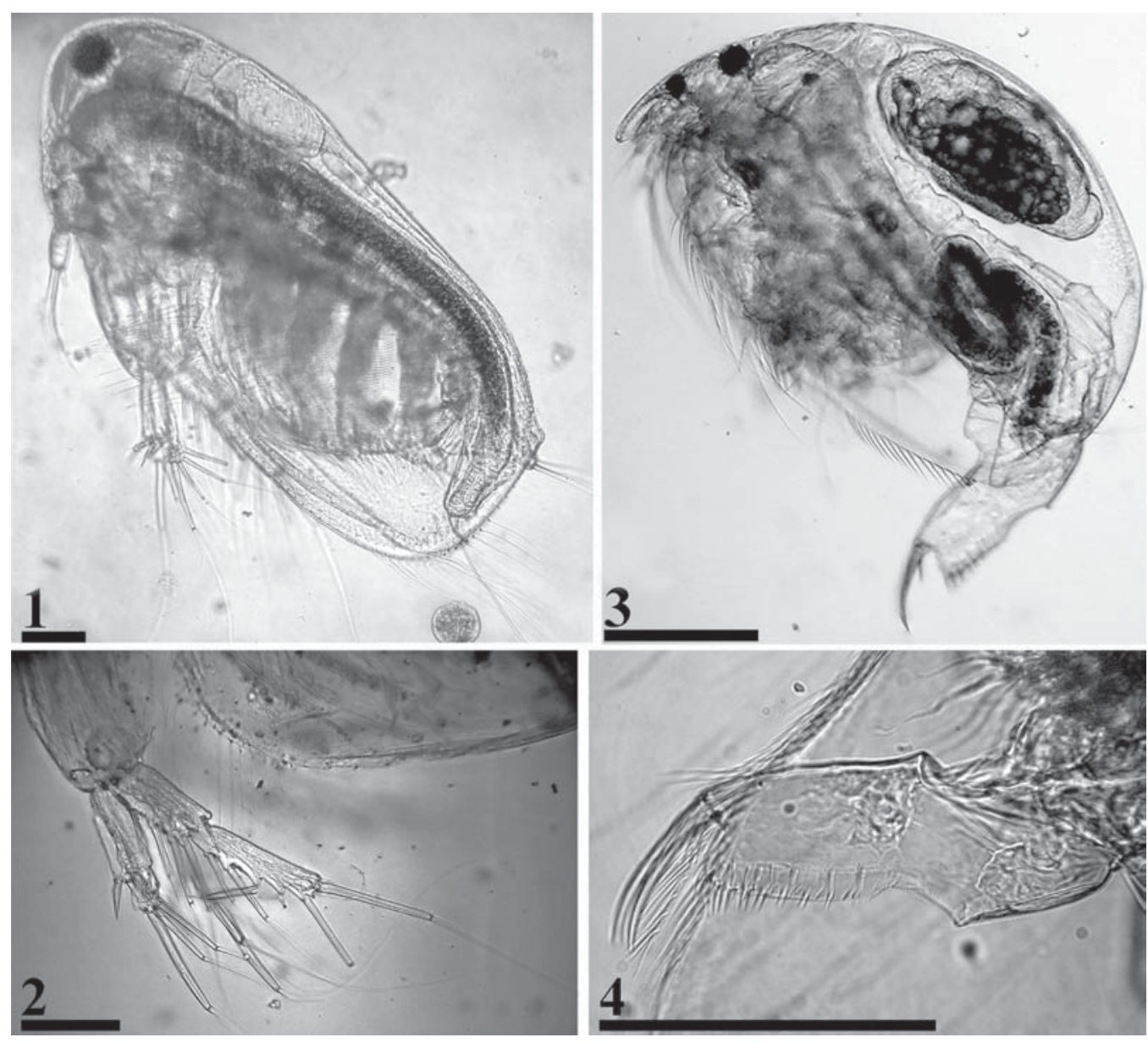

Figs. 1-4. Cladocerans of the hot springs of Palli, State of Maharashtra, India.

1-2 - Latonopsis cf. australis, general view and antenna II; 3-4 - Alona cambouei, general view and postabdomen. Scale bars $0.1 \mathrm{~mm}$.

Рис. 1-4. Ветвистоусые ракообразные горячих источников Пали, Штат Махараштра, Индия. 1-2 - Latonopsis cf. australis, общий вид и антенна II; 3-4 - Alona cambouei, общий вид и постабдомен. Масштаб 0,1 мм.

Alona cambouei Sars, 1888 is a member of A. puchella-species group; among members of these groups, it is diagnosed by: (1) number of notches on posterior margin of head shield uneven; (2) three major head pores without connection between them; (3) only about 30 35 setae, significantly differentiated in size, at ventral margin of carapace; (4) prominent preanal angle of postabdomen; (5) postabdominal claw of moderate length, subequal to preanal portion of postabdomen; (6) basal spine ca. $0.25-0.3$ of the claw length; (7) size of female not more than $0.45 \mathrm{~mm}$ (Sinev, 2001). Michael and Sharma (1987) did not report Alona cambouei from India. Although this taxon is common in tropics of Old World including the Oriental zone (Sinev, 2001), it was never recorded from hot springs.

Diatoms and cyanobacteria, a possible food for the cladocerans, are quite numerous in Pali hot water springs (Kirtikar, 1968). So, not food, but, probably, temperature is a limiting factor for establishment of the populations of other cladocerans there. The upper limit of 
temperature was determined as $30^{\circ} \mathrm{C}$ for Daphnia and Ceriodaphnia (Mallin, Partin, 1989) and $32^{\circ} \mathrm{C}$ for chydorids (Bogatova, 1962), while temperatures of $42-44^{\circ} \mathrm{C}$ caused their immediate death (Brown, 1929). But Latonopsis is a tropical-subtropical taxon which normally occurs at $34-38^{\circ} \mathrm{C}$ (Korovchinsky, 2004); only $46^{\circ} \mathrm{C}$ is lethal for it (Brown, 1929). So, Latonopsis would occur in hot springs under temperature conditions normal for this animal. There are cladocerans which survive even under higher temperatures: for Macrothrix cf. rosea the lethal temperature is $50{ }^{\circ} \mathrm{C}$ (Brown, 1929)!

Probably, the population of Alona cambouei in Pali hot springs is also adapted to high temperature conditions, although thermal preferences of the chydoridae are inadequately studied (Bogatova, 1962). Such adaptations probably include biochemical adaptations which could be specially investigated.

\section{Acknowledgements}

We are grateful to Dr H. Ghate, Prof. H.J. Dumont, Prof. N.N. Smirnov and Dr A.Yu. Sinev for valuable comments and Dr K. Pai for providing the laboratory facilities. The study is supported by the Council for Scientific and Industrial Research and University Grants Commission Major Research Project (File No. 33334/2007 for SR), the Russian Foundation for Basic Research grant \#09-04-00201-a and the
«Biodiversity» Program of the Presidium of Russian Academy of Sciences (for AAK).

\section{References}

Bogatova I.B. 1962. [Lethal concentrations of oxygen, water temperature and $\mathrm{pH}$ for some representatives of the family Chydoridae] // Zool. Zh. Vol.41. P.58-62 [in Russian].

Brown L.A. 1929. The natural history of Cladocerans in relation to temperature // Amer. Nat. Vol.63. P.248264, 346-352, 443-454.

Forró L., Korovchinsky N.M., Kotov A.A., Petrusek A. 2008. Global diversity of cladocerans (Cladocera; Crustacea) in freshwater // Hydrobiologia. Vol.595. P.177-184.

Jana B.B. 1978. The plankton ecology of some thermal springs in West Bengal, India// Hydrobiologia. Vol.61. P.135-143.

Kirtikar K.R. 1968. Algae of the hot springs at Palli // Hydrobiologia. Vol.25. P.340-351.

Korovchinsky N.M. 2004. [Cladocerans of the order Ctenopoda of the world fauna (morphology, systematics, ecology, biogeography]. Moscow: KMK Scientific Press Ltd. 410 p. [in Russian].

Mallin M.A., Partin W.E. 1989. Thermal tolerances of common Cladocera // J. Fresh. Ecol. Vol.5. P.45-51.

Michael R.G., Sharma B.K. 1988. Fauna of India and ajancent countries. Indian Cladocera (Crustacea: Branchiopoda: Cladocera). Calcutta: Zoological Survey of India. $262 \mathrm{p}$.

Sinev A.Yu. 2001. Separation of Alona cambouei Guerne \& Richard, 1893 from Alona pulchella King, 1853 (Branchiopoda: Anomopoda: Chydoridae) // Arthropoda Selecta. Vol.10. No.1. P.5-18.

Thomas J., Gonzalves E.A. 1968. Thermal algae of western India // Hydrobiologia. Vol.25. P.330-340.

Responsible editor Viatcheslav N. Ivanenko 